\title{
C-peptide exerts antithrombotic effects that are repressed by insulin in normal and diabetic mice
}

Received: 4 September 2005 / Accepted: 24 November 2005 / Published online: 23 February 2006

(C) Springer-Verlag 2006

\begin{abstract}
Aims/hypothesis: Diabetic macro- and microangiopathy are associated with a high risk of vascular complications. The diabetic patient exhibits a pathological coagulation state, with an increased synthesis of coagulation factors and plasminogen activator inhibitor 1 (PAI-1) as well as an enhanced aggregation of platelets. Previous studies have shown that C-peptide can reduce leucocyteendothelial cell interaction and improve microvascular blood flow in patients with type 1 diabetes. In the present study, we examined in vivo whether C-peptide is able to reduce platelet activation and through that microvascular thrombus formation. Materials and methods: In the microvessels of cremaster muscle preparations taken from normal and diabetic mice, ferric chloride-induced thrombus formation was analysed using intravital fluorescence microscopy. Results: I.V. administration of C-peptide in high dose $(70 \mathrm{nmol} / \mathrm{kg})$, but not in low dose $(7 \mathrm{nmol} / \mathrm{kg})$, caused a significant delay in arteriolar and venular thrombus growth in normal and diabetic mice. This effect was repressed by cremaster muscle superfusion with insulin $(100 \mu \mathrm{U} / \mathrm{ml})$ in diabetic animals, but particularly in normal animals. In parallel, immunohistochemistry demonstrated a higher number of PAI-1-expressing vessels in cremaster muscle tissue from control animals and from animals treated with C-peptide and insulin compared with tissue from animals with C-peptide treatment application alone. Conclusions/interpretation: We conclude that
\end{abstract}

N. Lindenblatt $\cdot$ B. Braun $\cdot$ B. Vollmar $(\bowtie)$

Department of Experimental Surgery, University of Rostock, Schillingallee 70 ,

18055 Rostock, Germany

e-mail: brigitte.vollmar@med.uni-rostock.de

Tel.: +49-381-4946220

Fax: +49-381-4946222

N. Lindenblatt $\cdot$ E. Klar

Department of General Surgery, University of Rostock, Rostock, Germany

M. D. Menger

Department of Clinical and Experimental Surgery,

University of Saarland,

Homburg-Saar, Germany
C-peptide possesses antithrombotic actions in vivo. A causal role of PAI-1 in this scenario needs to be further addressed. However, the reversal of C-peptide action by insulin may invalidate the use of this peptide as a treatment option to improve rheology and microcirculation in diabetic patients.

Keywords C-peptide · Diabetes · Insulin · In vivo microscopy $\cdot$ Microvascular thrombosis ·

Platelets $\cdot$ Streptozotocin

Abbreviations FITC: fluorescein isothiocyanate GPIIb/IIIa: glycoprotein IIb/IIIa $\cdot \mathrm{Na}^{+}-\mathrm{K}^{+}$-ATPase: sodium potassium ATPase $\cdot$ NO: nitric oxide $\cdot$ PAI-1: plasminogen activator inhibitor 1 - RBC: red blood cell - TRAP: thrombin-receptor-activating peptide

\section{Introduction}

The excess mortality and high morbidity of diabetic patients are predominantly determined by vascular dysfunctions. Diabetic microangiopathy not only manifests as nephropathy, retinopathy and delayed wound healing, but also predisposes the patient to the development of coronary artery, cerebrovascular and peripheral artery disease $[1,2]$. The pathophysiology of diabetic vasculopathy involves the dysfunction of the endothelium, which is caused by increased production of reactive oxygen species as a consequence of hyperglycaemia, which in turn inactivates the vasodilator nitric oxide (NO). As a consequence, nuclear factor $\mathrm{kB}$ is upregulated and the formation of vasoconstrictive prostanoids and endothelins is increased $[3,4]$. Plasminogen activator inhibitor 1 (PAI-1) levels have also been found to be elevated in diabetic patients, resulting in defective fibrinolysis and an increased risk for intravascular thrombosis $[5,6]$.

In addition to these endothelium-confined factors, platelet dysfunction [7-9] and an imbalance of plasmatic coagulation factors further contribute to a prothrombotic state in the diabetic patient. In particular, augmented 
synthesis of factor VII, thrombin, tissue factor and PAI-1 is detected in the diabetic patient, while anticoagulative substances, such as thrombomodulin and protein $\mathrm{C}$, are diminished [10-12].

Administration of C-peptide, the cleavage product from proinsulin, has been shown to improve skin microcirculation in patients with type 1 diabetes [13]. C-peptide further induces endothelial NO-synthetase and, thus, NO production [14]. In addition, it may reduce leucocyte-endothelium interaction through a diminution of endothelial P-selectin and intracellular adhesion molecule type 1 expression [15]. Based on this, insulin deficiency, and thus lack of antiadhesive C-peptide action, could be a causal factor in the development of procoagulative status in diabetic patients. We therefore used intravital fluorescence microscopy to investigate the effect of systemic C-peptide administration on microvascular thrombus formation in vivo in normal and diabetic mice. We additionally performed flow cytometric and immunohistological studies to characterise further the potential underlying cellular and molecular mechanisms. Since exogenous insulin application is essential for type 1 diabetic patients, we also tested the effect on microvascular thrombus formation of additional insulin application.

\section{Materials and methods}

Mouse cremaster muscle preparation

Upon approval by the local government, all experiments were carried out in accordance with the German legislation on protection of animals and the National Institutes of Health 'Guide for the Care and Use of Laboratory Animals' (Institute of Laboratory Animal Resources, National Research Council). Male C57BL/6 mice (Charles River, Sulzfeld, Germany) with a body weight of 20-25 g were anaesthetised with an i.p. injection of ketamine $(90 \mathrm{mg} / \mathrm{kg}$ body weight) and xylazine (25 mg/kg body weight) and a polyethylene catheter was placed into the right jugular vein to allow for administration of C-peptide and fluorescent dyes.

For the study of vascular thrombus formation, we used the opened cremaster muscle preparation, as described originally by Baez [16] and applied as a model of microvascular thrombus formation in previous studies [17-20]. After the preparation of the cremaster muscle, the animals were allowed to recover from surgery for $15 \mathrm{~min}$ before induction of thrombus formation.

In vivo thrombosis model

The cremaster muscle microcirculation was visualised by intravital fluorescence microscopy as described previously by our group [20]. Using a $\times 20$ water immersion objective (Achroplan $\times 20 / 0.50 \mathrm{~W}$; Zeiss, Jena, Germany) and $5 \%$ fluorescein isothiocyanate (FITC)-labelled dextran for contrast enhancement, blood flow was monitored in individual arterioles (diameter range 30-60 $\mu \mathrm{m}$ ) and venules (diameter range $40-80 \mu \mathrm{m}$ ), followed by superfusion with $25 \mu \mathrm{l}$ ferric chloride (12.5 mmol/l; Sigma, Steinheim, Germany) for induction of microvascular thrombosis. Recording of vessels was discontinued after blood flow in the vessel had ceased for at least $60 \mathrm{~s}$. As the rapid spreading of ferric chloride solution allowed only one or two arterioles and venules to be studied within each preparation, both left and right cremaster muscles were prepared for analysis of thrombotic vessel occlusion within each animal.

Analysis included the time periods until first standstill of perfusion and sustained cessation of blood flow as a result of complete vessel occlusion. To characterise the kinetics of microvascular thrombus formation, a red blood cell (RBC) velocity profile was determined using the line-shift method (CapImage; Zeintl, Heidelberg, Germany). Microcirculatory analysis also included the determination of vessel diameter and RBC velocity before thrombus induction with calculation of vascular wall shear rates, based on the Newtonian definition $\gamma=8 \times V / D$, where $V$ represents the RBC-velocity divided by 1.6 according to the Baker-Wayland factor [21] and $D$ represents the individual inner vessel diameter. The wall shear rate calculated might differ from values given in studies using different methods, such as the dual-slit photodiode technique and Doppler flowmetry $[22,23]$; however, it will fit well with values found in studies using the line-shift method or comparable systems $[20,24,25]$.

\section{Experimental groups and protocol}

Experiments were performed in normal and diabetic mice. Diabetes was induced by application of streptozotocin (40 mg/kg i.p.) on five consecutive days. Animals were kept in their accustomed environment and monitored for polyuria for the following 35-40 days. Starting on day 42 the diabetic metabolic state was confirmed by repeated positive testing for hyperglycaemia and glucosuria. Glucosuria was tested with test strips (Medi-test, Combi 3A; Macherey-Nagel, Düren, Germany) and was considered positive if the glucosuria was $>56 \mathrm{mmol} / \mathrm{l}$ on five consecutive days. Hyperglycaemia was confirmed by blood glucose testing with a digital glucometer (elite 2000; Beyer Diagnostics GmbH, Munich, Germany). Mice were considered diabetic if their blood glucose levels were $>11.1 \mathrm{mmol} / 1$ for three consecutive days.

Human C-peptide was administered to mice via the right jugular vein in a low dose of $7 \mathrm{nmol} / \mathrm{kg}(n=6)$ and a high dose of $70 \mathrm{nmol} / \mathrm{kg}(n=6) 15 \mathrm{~min}$ before the experiment. Control animals received equivalent volumes of heat-inactivated C-peptide $\left(30 \mathrm{~min}\right.$ at $\left.95^{\circ} \mathrm{C}\right)(n=14)$. The C-peptide concentrations were chosen because previous experiments had shown that injection of $130 \mathrm{nmol} / \mathrm{kg}$ human C-peptide into rats increased the physiological C-peptide plasma levels ten-fold $3 \mathrm{~h}$ after injection [26]. Therefore, the higher dose of $70 \mathrm{nmol} / \mathrm{kg}$ used in this study is likely to induce an approximately five-fold increase in C-peptide plasma level, which has 
been shown to correct vascular permeability and neuronal dysfunction in diabetic rats [26]. Additionally, Scalia et al. demonstrated that this concentration of C-peptide inhibited leucocyte-endothelial interaction during acute endothelial dysfunction [15]. To examine the role of insulin in Cpeptide function, the cremaster muscles of animals treated with C-peptide at either low $(7 \mathrm{nmol} / \mathrm{kg} ; n=4)$ or high (70 nmol/kg; $n=4)$ dose were superfused with insulin solution at a concentration of $100 \mu \mathrm{U} / \mathrm{ml}$ before thrombus induction. This concentration was applied because postprandial insulin levels in humans typically reach 60$80 \mu \mathrm{U} / \mathrm{ml}$. Insulin was applied topically because systemic application of insulin might have resulted in uncontrollable lowering of blood glucose levels and thus unstable metabolic conditions. Identical sets of experiments were performed in diabetic mice with systemic C-peptide administration at low $(n=5)$ and high $(n=4)$ doses, using heat-inactivated C-peptide $(n=11)$ as well as with additional insulin superfusion at low $(n=4)$ and high $(n=4)$ doses of C-peptide.

To rule out a difference in the effect of $\mathrm{C}$-peptide and insulin between systemic and topical application and to further clarify the effect of insulin application alone, additional in vivo experiments were performed superfusing the cremaster muscle with insulin $(100 \mu \mathrm{U} / \mathrm{ml})$ alone in normal $(n=4)$ and diabetic $(n=4)$ mice. In addition, cremaster muscle preparations were superfused with insulin $(100 \mu \mathrm{U} / \mathrm{ml})$ and C-peptide $(7 \mathrm{nmol} / \mathrm{l})$ in normal $(n=4)$ and diabetic $(n=5)$ animals.

Human blood collection and preparation of platelet-rich plasma

Following acquisition of informed consent, blood was drawn from the left cubital vein of healthy volunteers using a 21-gauge needle into 5-ml S-Monovettes 9NC (Sarstedt, Nümbrecht, Germany) (1:10 citrate, v/v). After centrifugation for $15 \mathrm{~min}$ at $110 \mathrm{~g}$ and room temperature (GS-6R Centrifuge; Beckman Coulter, Fullerton, CA, USA), platelet-rich plasma was transferred to a separate tube. Platelet count was assessed with a Cell Counter (Sysmex KX-21; Sysmex, Norderstedt, Germany) and adjusted to $2 \times 10^{8} / \mathrm{ml}$ by dilution with PBS. Aliquots of platelet-rich plasma were transferred into a $37^{\circ} \mathrm{C}$ water-bath to rest for $30 \mathrm{~min}$ to eliminate isolation-induced platelet activation.

Flow cytometric analysis of P-selectin and glycoprotein IIb/IIIa expression

For evaluation of receptor expression under resting conditions, $50 \mu \mathrm{l}$ of platelet suspensions were incubated for $30 \mathrm{~min}$ with the isotype-specific control antibody, the P-selectin antibody or the glycoprotein IIb/IIIa (GPIIb/ IIIa) antibody in the presence of C-peptide at concentrations of either 0.3 or $1 \mathrm{nmol} / 1$. Platelet suspensions without C-peptide served as controls. A similar set of experiments was carried out following exposure to thrombin-receptor- activating peptide (TRAP) for maximal platelet activation ( $2.5 \mathrm{mmol} / \mathrm{l})$.

C-peptide concentrations of 0.3 and $1.0 \mathrm{nmol} / 1$ were chosen because the physiological concentration of Cpeptide in human blood ranges between 0.5 and $1.5 \mathrm{nmol} / 1$. In addition, reports studying a potential C-peptide receptor on renal tubular cells showed a half-saturation at a Cpeptide concentration of $0.3 \mathrm{nmol} / 1$ and a full saturation at $0.9 \mathrm{nmol} / \mathrm{l} \mathrm{C}$-peptide [27]. An additional set of experiments was carried out, adding insulin at final concentrations of 10 and $100 \mu \mathrm{U} / \mathrm{ml}$ (which cover fasting [6-25 $\mu \mathrm{U} / \mathrm{ml}$ and postprandial $[60-100 \mu \mathrm{U} / \mathrm{ml}$, maximum $200 \mu \mathrm{U} / \mathrm{ml}]$ insulin levels in humans [28]) alone and in combination with C-peptide concentrations of 0.3 and $1.0 \mathrm{nmol} / \mathrm{l}$. Then, platelets were rapidly cooled on ice and diluted with $1 \mathrm{ml}$ $4^{\circ} \mathrm{C} 1 \%$ paraformaldehyde in PBS (Cell Fix; Becton Dickinson, Heidelberg, Germany). After fixation, platelets were centrifuged at $300 \mathrm{~g}$ for $4 \mathrm{~min}$ at $4^{\circ} \mathrm{C}$ and washed twice with PBS. The supernatant was decanted and the pellet was resuspended in PBS for flow cytometry.

Expression of P-selectin on platelets was investigated by direct immunofluorescence using a monoclonal antihuman FITC-coupled P-selectin antibody (Santa Cruz Biotechnology, Heidelberg, Germany), diluted 1:50 (v/v) with staining medium $(0.1 \%$ sodium azide and $2 \%$ FCS in PBS). In an additional set of experiments a FITCcoupled PAC-1 antibody (Becton Dickinson Biosciences, Heidelberg, Germany) directed against the activated conformation of GPIIb/IIIa was employed [29]. A FITCcoupled IgG1 isotype-matched control antibody (Santa Cruz Biotechnology) was used to exclude unspecific binding. Flow cytometry was performed within the next hour.

The FACScan flow cytometer (Becton Dickinson) was calibrated with fluorescent standard microbeads (CaliBRITE Beads; Becton Dickinson) for accurate instrument setting. Platelets were identified by their characteristic forward and sideward scatter light and were selectively analysed for their fluorescence properties using the CellQuest program (Becton Dickinson) with assessment of 20,000 events per sample. The relative fluorescence intensity of a given sample was calculated by subtracting the signal obtained when cells were incubated with the isotype-specific control antibody from the signal generated by cells incubated with the test antibody.

Histology and immunohistochemistry

At the end of each experiment, the cremaster muscle was fixed in 4\% phosphate-buffered formalin for 2-3 days and embedded in paraffin. From the paraffin-embedded tissue blocks, 4- $\mu \mathrm{m}$ sections were cut and stained with haematoxylin and eosin for histological analysis. For immunohistochemical demonstration of PAI-1, sections collected on poly-L-lysine-coated glass slides were treated by microwave for antigen unmasking. Goat polyclonal antiPAI-1 (1:200; Santa Cruz Biotechnology) was used as primary antibody and incubated for $90-120 \mathrm{~min}$ at room 
temperature, followed by a horseradish peroxidase-conjugated donkey anti-goat antibody (1:25; Santa Cruz Biotechnology) and development using DAB substrate as chromogen. The sections were counterstained with haematoxylin and examined by light microscopy (Zeiss Axioscop 40; Zeiss).

\section{Chemicals and drugs}

Human 31-residue C-peptide (Sigma) was dissolved in $0.5 \mathrm{~mol} / \mathrm{l}$ acetic acid with further dilutions being made with $0.9 \%$ saline, as previously described [15]. Human Cpeptide was applied because of its simple availability and similar structure compared with rat or mouse C-peptides. Human C-peptide has been used in several small animal models and has been shown to induce positive effects on vascular and neuronal dysfunction as well as on leucocyteendothelial cell dysfunction $[15,26]$. Streptozotozin (Sigma) was dissolved in citrate buffer $(\mathrm{pH} 4.5,0.1 \mathrm{~mol} / \mathrm{l})$ and used directly following preparation. Porcine insulin was also purchased from Sigma and dissolved in PBS to final concentrations of 10 and $100 \mu \mathrm{U} / \mathrm{ml}$. As insulin from different species interacts with porcine insulin sera to a similar degree [30], porcine insulin was chosen because it is more easily available and is cheaper. TRAP was purchased from Bachem (Bubendorf, Germany) and dissolved in PBS to yield a $2.5 \mathrm{mmol} / \mathrm{l}$ stock solution. All solutions were stored in the dark at a maximum temperature of $-20^{\circ} \mathrm{C}$.

Statistical analysis

After proving the assumption of normality and equal variance across groups, differences between groups were assessed using one-way ANOVA followed by the appropriate post hoc comparison test. All data were expressed as means \pm SEM and overall statistical significance was set at $p<0.05$. Linear regression analysis was performed to evaluate significant correlations between kinetics of thrombus formation and PAI-1 expression. Statistics and graphics were performed using the software packages SigmaStat and SigmaPlot (Jandel Corporation, San Rafael, CA, USA).

\section{Results}

In vivo thrombosis model

The effect of systemic application of C-peptide in low $(7 \mathrm{nmol} / \mathrm{kg})$ and high $(70 \mathrm{nmol} / \mathrm{kg})$ doses was assessed in vivo by superfusion of microvessels with ferric chloride solution, which resulted in complete thrombotic occlusion of the individually exposed vessel.

At baseline, i.e. before thrombus induction, animals did not significantly differ between the groups with regard to the diameter and wall shear rates in arterioles and venules (Table 1). Thus, the distinct times until complete vessel occlusion are only barely attributable to differences in microhaemodynamics.

Effect of low-dose C-peptide on microvascular thrombosis

Quantitative analysis of ferric chloride-induced thrombus formation in normal controls, i.e. animals that received heat-inactivated C-peptide, revealed complete occlusion of venules and arterioles at $449 \pm 55 \mathrm{~s}$ and $411 \pm 76 \mathrm{~s}$, respectively (Fig. 1a). C-peptide neither alone nor in

Table 1 Vessel diameters $(\mu \mathrm{m})$ and wall shear rates $\left(\gamma ; \mathrm{s}^{-1}\right)$ in mice cremaster muscle microvessels prior to ferric chloride-induced thrombus formation

\begin{tabular}{|c|c|c|c|c|}
\hline & \multicolumn{2}{|l|}{ Arterioles } & \multicolumn{2}{|l|}{ Venules } \\
\hline & Diameter & $\gamma$ & Diameter & $\gamma$ \\
\hline \multicolumn{5}{|l|}{ Normal } \\
\hline Control & $45 \pm 4$ & $116 \pm 9$ & $51 \pm 6$ & $73 \pm 12$ \\
\hline C-peptide $7 \mathrm{nmol} / \mathrm{kg}$ & $52 \pm 7$ & $133 \pm 32$ & $72 \pm 10$ & $56 \pm 9$ \\
\hline C-peptide $7 \mathrm{nmol} / \mathrm{kg}+$ insulin & $55 \pm 4$ & $134 \pm 9$ & $61 \pm 4$ & $99 \pm 12$ \\
\hline Control & $37 \pm 4$ & $129 \pm 18$ & $46 \pm 4$ & $63 \pm 18$ \\
\hline C-peptide $70 \mathrm{nmol} / \mathrm{kg}$ & $45 \pm 4$ & $150 \pm 25$ & $50 \pm 4$ & $98 \pm 16$ \\
\hline $\mathrm{C}$-peptide $70 \mathrm{nmol} / \mathrm{kg}+$ insulin & $54 \pm 5$ & $127 \pm 13$ & $58 \pm 5$ & $94 \pm 4$ \\
\hline \multicolumn{5}{|l|}{ Diabetic } \\
\hline Control & $48 \pm 3$ & $134 \pm 12$ & $53 \pm 5$ & $96 \pm 8$ \\
\hline C-peptide $7 \mathrm{nmol} / \mathrm{kg}$ & $55 \pm 5$ & $140 \pm 9$ & $66 \pm 6$ & $141 \pm 46$ \\
\hline C-peptide $7 \mathrm{nmol} / \mathrm{kg}+$ insulin & $41 \pm 6$ & $198 \pm 40$ & $56 \pm 7$ & $73 \pm 6$ \\
\hline Control & $56 \pm 6$ & $128 \pm 9$ & $56 \pm 6$ & $120 \pm 14$ \\
\hline C-peptide $70 \mathrm{nmol} / \mathrm{kg}$ & $38 \pm 4$ & $136 \pm 32$ & $50 \pm 4$ & $140 \pm 25$ \\
\hline C-peptide $70 \mathrm{nmol} / \mathrm{kg}+$ insulin & $48 \pm 7$ & $173 \pm 37$ & $61 \pm 5$ & $75 \pm 9$ \\
\hline
\end{tabular}

Values are given as means \pm SEM; for further information, see Materials and methods 
combination with insulin had a major influence on these microvascular occlusion times in normal animals (Fig. 1a). Moreover, microvascular thrombus formation in diabetic mice did not differ between control animals and those that received low-dose C-peptide alone or in combination with insulin (Fig. 1b), ranging between 375 and $510 \mathrm{~s}$ for arterioles and 400 and $570 \mathrm{~s}$ for venules.

Effect of high-dose C-peptide on microvascular thrombosis

In contrast, the application of a high dose of C-peptide caused a significant delay in arteriolar and venular thrombus growth and in occlusion time in both normal (Fig. 2a) and diabetic animals (Fig. 2b). Notably, this prolongation in microvascular thrombus formation with high-dose C-peptide exposure was abolished by superfusion of the cremaster muscle with insulin in normal mice and resulted in complete occlusion of arterioles and venules within the time periods, as observed in controls (Fig. 2a). As in normal mice, insulin superfusion repressed the C-peptide-induced delay in thrombotic vessel occlusion in diabetic mice towards the values found in controls (Fig. 2b). This effect was also seen when the cremaster muscle was superfused with insulin and C-peptide, as indicated by the comparable arteriolar and venular occlusion times in normal and diabetic animals. Insulin superfusion alone resulted in even shorter times until complete vessel occlusion compared with combined insulin and C-peptide treatment in normal mice, but in particular in diabetic animals (Table 2).

Flow cytometric analysis of platelet P-selectin and GPIIb/IIIa expression

Upon incubation with C-peptide alone or in combination with insulin, spontaneous expression of P-selectin and



Fig. 1 Occlusion times of arterioles (open bars) and venules (filled bars) upon ferric-chloride-induced thrombus formation in normal (a) and diabetic (b) mice following treatment with heat-inactivated
GPIIb/IIIa did not show a marked change and was below $10 \%$. Moreover, both C-peptide alone and C-peptide combined with insulin failed to affect maximal P-selectin and GPIIb/IIIa expression, as induced by TRAP exposure of platelets (data not shown).

\section{PAI-1 immunohistochemistry}

PAI-1 was expressed within the endothelium of arterioles and venules, while little, if any, immunoreactivity was detected within the surrounding muscle tissue (Fig. 3a,b). Immunohistochemistry of cremaster muscle tissue with low-dose C-peptide exposure in both normal and diabetic animals exhibited a slight reduction in the fraction of PAIexpressing vessels when compared to their corresponding normal and diabetic controls (Fig. 4a,b). Interestingly, in animals with additional insulin superfusion, the fraction of PAI-expressing vessels was found to be higher than that in animals that received C-peptide alone and even exceeded that found in controls (Fig. 4b).

In normal and diabetic animals that received C-peptide at the high dose of $70 \mathrm{nmol} / \mathrm{kg}$, PAI-1 expression was markedly reduced, with only $1.5-2 \%$ of all vessels displaying specific immunoreactivity (Fig. 5a,b). Notably, insulin superfusion in diabetic animals reversed the Cpeptide-induced repression of PAI-expression towards the values found in controls $(\sim 10 \%)$, while in normal animals the fraction of PAI-expressing vessels averaged almost $30 \%$ upon C-peptide and insulin superfusion (Fig. 5a,b). Superfusion of the cremaster muscle with both C-peptide ( $7 \mathrm{nmol} / \mathrm{l})$ and insulin caused a slight, but not significant, increase in vascular PAI-1 expression in relation to systemic C-peptide application plus superfusion with insulin. Insulin superfusion alone resulted in a marked and significant increase in endothelial PAI-1 expression within the cremaster muscle compared with additional C-peptide treatment (Table 2).

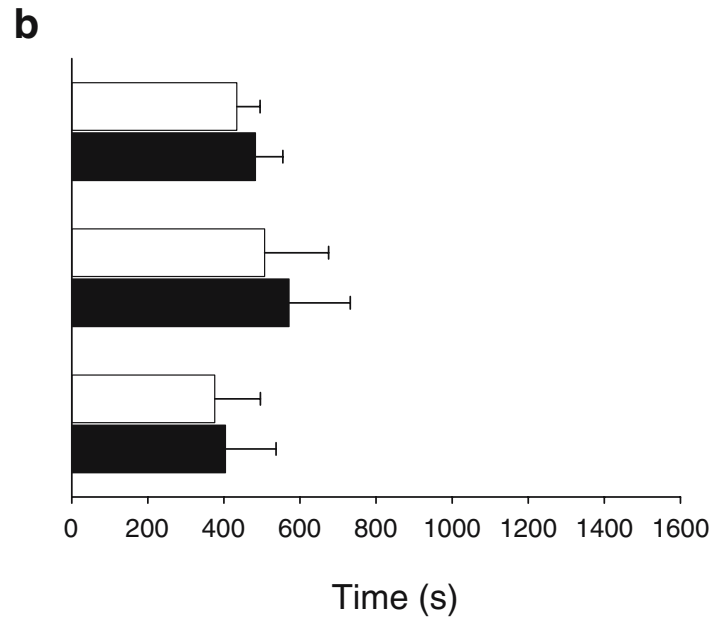

C-peptide (control), C-peptide at low dose $(7 \mathrm{nmol} / \mathrm{kg})$ and Cpeptide at low dose $(7 \mathrm{nmol} / \mathrm{kg})$ with additional superfusion of insulin $(100 \mu \mathrm{U} / \mathrm{ml})$. Values are given as means \pm SEM 
a

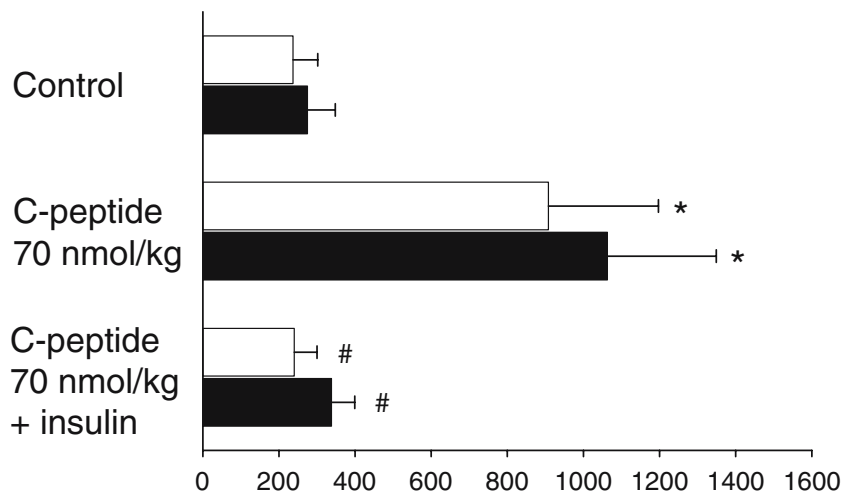

Time (s) b

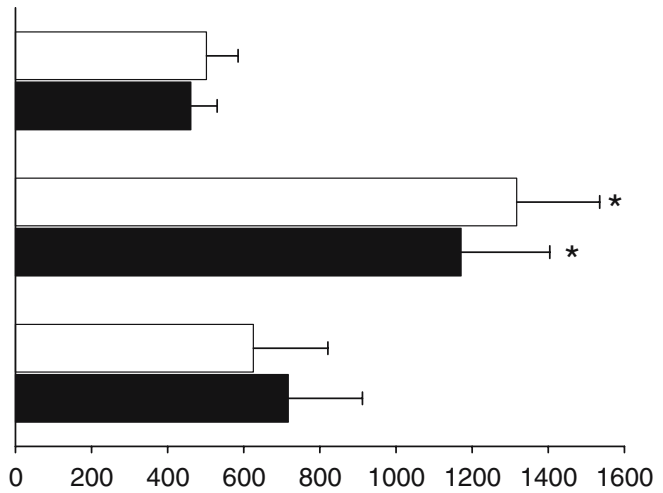

Time (s)
Fig. 2 Occlusion times of arterioles (open bars) and venules (filled bars) upon ferric-chloride-induced thrombus formation in normal (a) and diabetic (b) mice following treatment with heat-inactivated C-peptide (control), C-peptide at high dose (70 nmol/ $\mathrm{kg})$, C-peptide

\section{Discussion}

The main reason for morbidity and mortality in diabetic patients is cardiovascular complications. However, the link between diabetes and macro- and microangiopathic impairment is still not fully understood. Moreover, sufficient treatment options have not been established, despite improved glycaemic control of diabetes. To find novel therapeutic strategies and, in particular, to counteract the procoagulative status in diabetic patients, we studied the effect of proinsulin C-peptide administration on microvascular thrombus formation in vivo.

Our results demonstrate that administration of i.v. Cpeptide at $70 \mathrm{nmol} / \mathrm{kg}$ leads to a significant deceleration of microvascular thrombus formation not only in diabetic but also in normal mice. This provides evidence for a substantial antithrombotic effect of proinsulin C-peptide. These in vivo results are further underlined by immunohistological findings, demonstrating that C-peptide administration prompts a decrease in vascular PAI-1 expression. Of interest, insulin application completely blunted the anticoagulative effect of C-peptide in normal and diabetic mice. This is supported by the fact that the percentage of at high dose $(70 \mathrm{nmol} / \mathrm{kg})$ with additional superfusion of insulin $(100 \mu \mathrm{U} / \mathrm{ml})$. Values are given as means $\pm \mathrm{SEM} ;{ }^{*} p<0.05 \mathrm{vs}$ control; $\# p<0.05$ vs C-peptide high dose $(70 \mathrm{nmol} / \mathrm{kg})$

PAI-1-expressing vessels within the cremaster muscle tissue was increased in animals which underwent Cpeptide treatment and consecutive insulin superfusion compared with animals treated with C-peptide alone. The effect of C-peptide and insulin treatment was similar regardless of whether a local or systemic mode of $\mathrm{C}$ peptide application was chosen. Insulin superfusion alone caused even faster vascular occlusion times, once more underlining the prothrombotic effect of insulin.

FACScan analysis of human platelets did not reveal major changes upon C-peptide and C-peptide + insulin exposure. Despite differences in size, number and ultrastructural morphology human and murine platelets have been shown to exert similar organelle and glycoprotein subcellular distributions [31]. The GPIIb/IIIa receptor in particular exerts comparable functions during platelet activation and aggregation in humans and mice [32]. However, we are aware that species differences cannot be completely excluded.

Since the discovery of insulin biosynthesis and the subsequent identification of proinsulin and C-peptide, numerous studies have been undertaken to characterise a distinct role for C-peptide apart from being merely a

Table 2 Vessel occlusion times and percentage of PAI-1-expressing vessels in mice cremaster muscle upon ferric chloride-induced thrombus formation

Arteriolar occlusion time (s) Venular occlusion time (s) PAI-1-expressing vessels (\%)

Normal

Superfusion of C-peptide ( $7 \mathrm{nmol} / \mathrm{l})+$ insulin

Superfusion of insulin

$319 \pm 101$

$370 \pm 101$

$34.6 \pm 2.4$

Diabetic

$278 \pm 68$

$279 \pm 76$

$56.7 \pm 8.8$

Superfusion of C-peptide $(7 \mathrm{nmol} / \mathrm{l})+$ insulin

$510 \pm 70$

$672 \pm 77$

$17.6 \pm 2.8$

Superfusion of insulin

$182 \pm 84$

$238 \pm 84$

$63.4 \pm 1.4$

Values are given as means \pm SEM; for further information, see Materials and methods and Results 
Fig. 3 Immunohistochemical staining of PAI-1 expression in cremaster muscle tissue after treatment with (a) heat-inactivated $\mathrm{C}$-peptide (control) and (b) C-peptide at the high dose $(70 \mathrm{nmol} / \mathrm{kg}$ ). Note the marked expression of PAI-1 in the control animal with preferential localisation at the vascular site, while there was little immunostaining for PAI-1 in the C-peptide-treated animal. Magnification $\times 400$
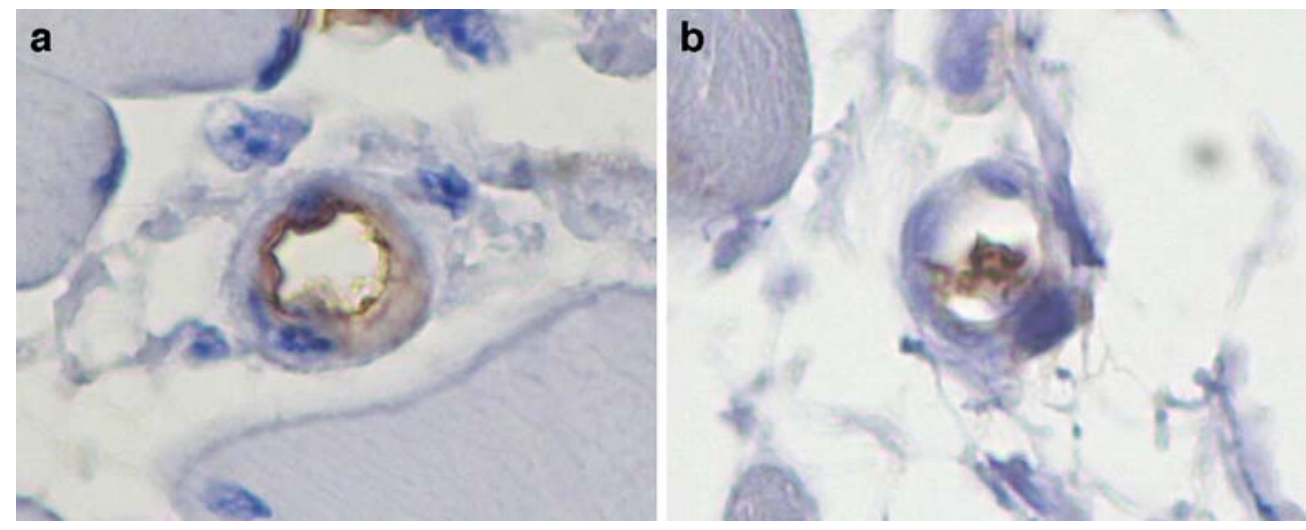

'connecting' peptide [33]. Despite some effects reported on glucagon release in the rat pancreas [34], it became common opinion that C-peptide had no biological activity on its own. However, evidence for multiple beneficial effects of C-peptide administration in diabetic patients has been rising over the past decade.

Forst et al. reported positive effects of C-peptide administration on skin microcirculation in patients with type 1 diabetes [13]. Moreover, C-peptide has been demonstrated to cause a dilatation of skeletal muscle arterioles that was probably based on increased NO production and could only be observed in the presence of insulin [35]. This NOreleasing effect of C-peptide was confirmed in a study on leucocyte-endothelium interaction after C-peptide administration in the mesentery of normal rats [15] and in vitro in bovine aortic endothelial cells, which showed a time- and concentration-dependent release of NO [14]. It has further been demonstrated that C-peptide elicits a concentrationdependent stimulation of $\mathrm{Na}^{+}-\mathrm{K}^{+}$-ATPase activity in renal tubular cells [36]. Consistent with this, the activity of $\mathrm{Na}^{+}-\mathrm{K}^{+}$-ATPase was reduced in membranes of erythrocytes of diabetic patients, which led to a reduced erythrocyte deformability and an increased blood viscosity.

a

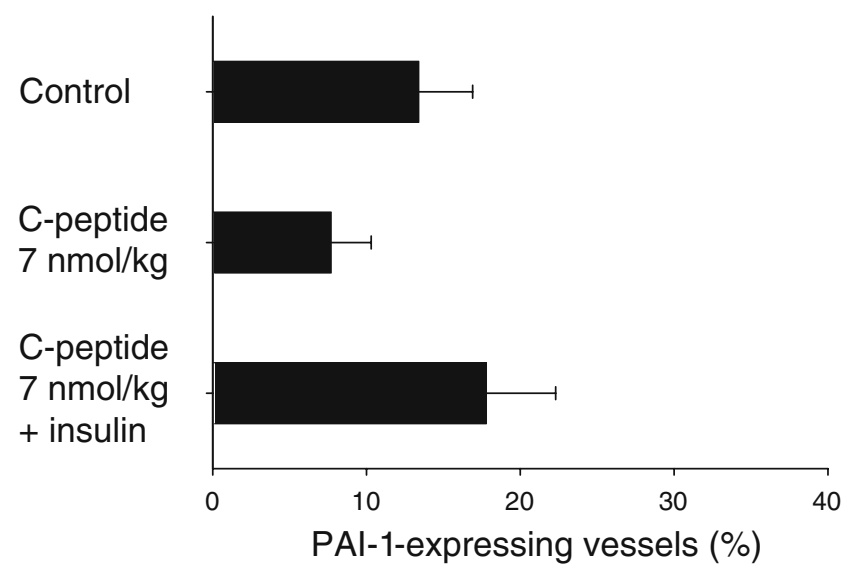

Fig. 4 Immunohistological analysis of vascular PAI-1 expression represented by percentage of positively stained vessels within the cremaster muscle for normal (a) and diabetic (b) mice after pretreatment with inactivated C-peptide (control), C-peptide at low
C-peptide infusion restored RBC deformability and microvascular blood flow concomitant with $\mathrm{Na}^{+}-\mathrm{K}^{+}$-ATPase activity $[37,38]$. As a consequence it has been assumed that beneficial effects of C-peptide on microvascular blood flow and haemorrheology are exerted largely via stimulation of endothelial NO-synthetase (with subsequent NO-release) and $\mathrm{Na}^{+}-\mathrm{K}^{+}$-ATPase of erythrocytes [39].

Several studies have suggested that PAI-1 plays a major role in the pathogenesis of atherosclerosis and represents a risk factor for coronary heart disease [1, 40]. PAI-1 is the most important physiological inhibitor of tissue plasminogen activator, which activates plasminogen to plasmin and therefore exerts prothrombotic effects. Its role in the insulin-resistance syndrome has been defined in the past [41]. ApoE ${ }^{-/}$mice with high PAI-1 levels exhibited a prothrombotic phenotype with shortened time to thrombotic vessel occlusion in a model of ferric-chloride-induced carotid artery injury [42]. In this study, we provide evidence that C-peptide possesses antithrombotic effects that could eventually be related to the biology of PAI- 1 . We show that cremaster muscle tissue of control animals and animals treated with C-peptide and insulin present with a higher number of PAI-1-expressing vessels compared

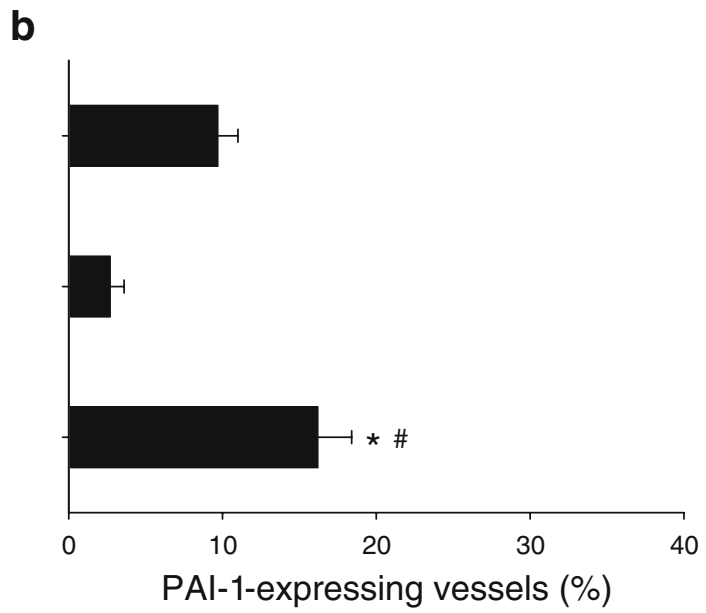

dose $(7 \mathrm{nmol} / \mathrm{kg})$ and C-peptide at low dose with additional superfusion of insulin $(100 \mu \mathrm{U} / \mathrm{ml})$. Values are given as means $\pm \mathrm{SEM} ;{ }^{*} p<0.05$ vs control; $\# p<0.05$ vs C-peptide low dose $(7 \mathrm{nmol} / \mathrm{kg})$ 


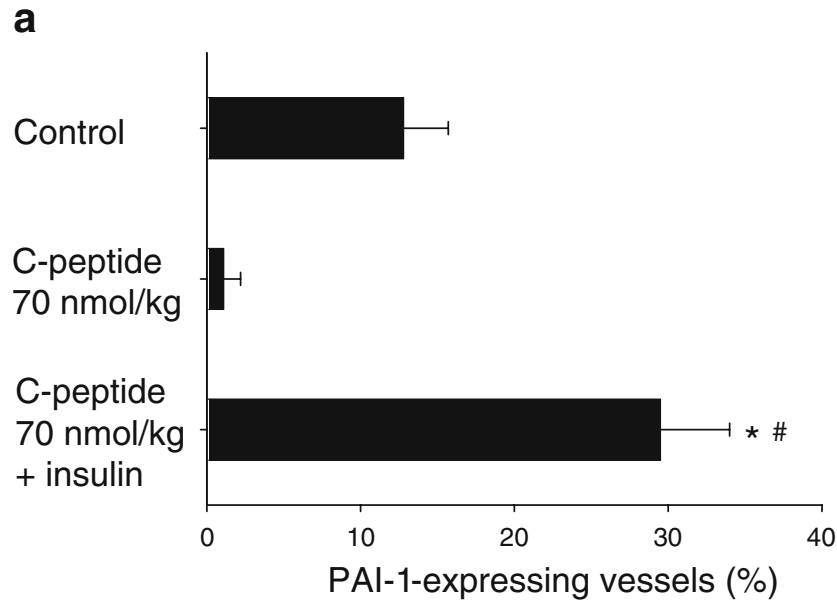

b

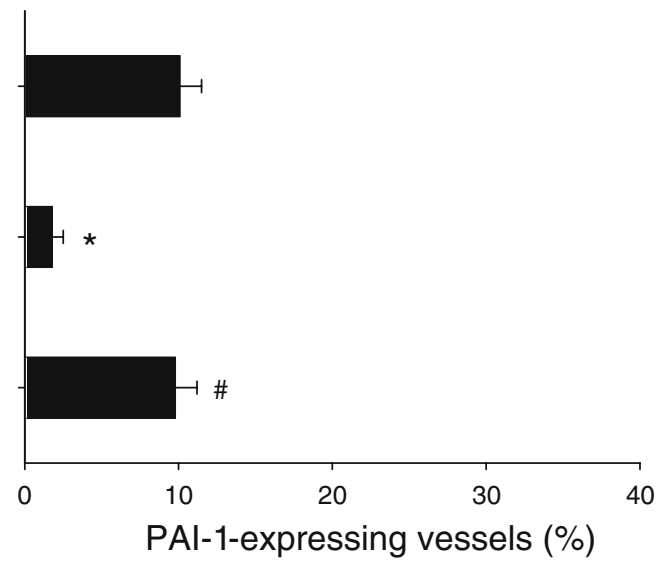

Fig. 5 Immunohistological analysis of vascular PAI-1 expression represented by percentage of positively stained vessels within the cremaster muscle for normal (a) and diabetic (b) mice after pretreatment with inactivated C-peptide (control), C-peptide at high

dose $(70 \mathrm{nmol} / \mathrm{kg})$, C-peptide at high dose with additional superfusion of insulin $(100 \mu \mathrm{U} / \mathrm{ml})$. Values are given as means $\pm \mathrm{SEM}$; ${ }^{*} p<0.05$ vs control; $\# p<0.05$ vs C-peptide high dose $(70 \mathrm{nmol} / \mathrm{kg})$

with animals given only C-peptide, implying a link between reduced PAI-1 expression and the antithrombotic effect of C-peptide. However, postulation of a direct causal relationship between C-peptide and PAI-1 requires further mechanistic investigation.

The effects of insulin on vascular biology have been controversially discussed in the past. Insulin has been found to mediate NO-induced vasodilatation [43], to inhibit platelet aggregation by inducing the synthesis of prostacyclin in endothelial cells, to upregulate prostacyclin receptors and downregulate $\alpha_{2}$-adrenergic receptors on platelets, and to release tissue plasminogen activator from the platelet membrane [44]. On the other hand, insulin caused an two-fold upregulation of PAI-1 gene expression within $3 \mathrm{~h}$ in rabbits, is found to be elevated in hyperinsulinaemic type 2 diabetic patients $[6,45]$ and results in overexpression of endothelin in vascular smooth muscle cells [46]. Moreover, insulin but not C-peptide enhanced platelet fibrinogen binding in vitro in platelets from type 1 diabetic patients and healthy subjects [47] and enhanced platelet aggregability and leucocyte CD11b expression in whole blood from healthy patients [48]. In line with this, we now show that insulin reverses the antithrombotic effects of C-peptide in normal and diabetic mice.

It has repeatedly been stated that positive effects of Cpeptide cannot be detected in healthy humans or animals but only in diabetic patients or animals that exhibit very low or missing C-peptide plasma levels $[49,50]$. This was explained by the binding characteristics of a presumed Gprotein-coupled membrane receptor [27] with saturation already at very low C-peptide concentrations. Thus, in healthy subjects with saturating physiological C-peptide levels there will be no additional effects upon exogenous C-peptide application. In contrast to that, we did not observe a difference in antithrombotic action of C-peptide between normal and diabetic animals. However, as it has been reported that C-peptide-induced prevention of vascu- lar dysfunction is mediated by non-chiral interactions instead of stereospecific receptors or binding sites, we propose that the antithrombotic property of $\mathrm{C}$-peptide and subsequently the effect of C-peptide on PAI-1 expression is more likely to be based on non-receptor actions.

Acknowledgements The authors would like to thank B. Blendow, D. Frenz and C. Vergien, Department of Experimental Surgery, University of Rostock, and Dr C. Zingler, Institute for Clinical Chemistry and Laboratory Medicine, University of Rostock, for their excellent technical assistance.

\section{References}

1. Calles-Escandon J, Cipolla M (2001) Diabetes and endothelial dysfunction: a clinical perspective. Endocr Rev 22:36-52

2. Creager MA, Luscher TF, Cosentino F, Beckman JA (2003) Diabetes and vascular disease: pathophysiology, clinical consequences, and medical therapy: Part I. Circulation 108:1527-1532

3. De Vriese AS, Verbeuren TJ, Van de Voorde J, Lameire NH, Vanhoutte PM (2000) Endothelial dysfunction in diabetes. Br J Pharmacol 130:963-974

4. Luft FC (2002) Proinflammatory effects of angiotensin II and endothelin: targets for progression of cardiovascular and renal diseases. Curr Opin Nephrol Hypertens 11:59-66

5. Auwerx J, Bouillon R, Collen D, Geboers J (1988) Tissue-type plasminogen activator antigen and plasminogen activator inhibitor in diabetes mellitus. Arteriosclerosis 8:68-72

6. Jokl R, Laimins M, Klein RL, Lyons TJ, Lopes-Virella MF, Colwell JA (1994) Platelet plasminogen activator inhibitor 1 in patients with type II diabetes. Diabetes Care 17:818-823

7. Vericel E, Januel C, Carreras M, Moulin P, Lagarde M (2004) Diabetic patients without vascular complication display enhanced basal platelet activation and decreased antioxidant status. Diabetes 53:1046-1051

8. Vinik AI, Erbas T, Park TS, Nolan R, Pittenger GL (2001) Platelet dysfunction in type 2 diabetes. Diabetes Care 24:1476-1485

9. Li Y, Woo V, Bose R (2001) Platelet hyperactivity and abnormal $\mathrm{Ca}^{2+}$ homeostasis in diabetes mellitus. Am J Physiol Heart Circ Physiol 280:H1480-H1489 
10. Ceriello A, Giacomello R, Stel G et al (1995) Hyperglycemiainduced thrombin formation in diabetes. The possible role of oxidative stress. Diabetes 44:924-928

11. Pandolfi A, Cetrullo D, Polishuck R et al (2001) Plasminogen activator inhibitor type 1 is increased in the arterial wall of type II diabetic subjects. Arterioscler Thromb Vasc Biol 21:1378-1382

12. Hafer-Macko CE, Ivey FM, Gyure KA, Sorkin JD, Macko RF (2002) Thrombomodulin deficiency in human diabetic nerve microvasculature. Diabetes 51:1957-1963

13. Forst T, Kunt T, Pohlmann T et al (1998) Biological activity of $\mathrm{C}$-peptide on the skin microcirculation in patients with insulindependent diabetes mellitus. J Clin Invest 101: 2036-2041

14. Wallerath T, Kunt T, Forst $T$ et al (2003) Stimulation of endothelial nitric oxide synthetase by proinsulin C-peptide. Nitric Oxide 9:95-102

15. Scalia R, Coyle KM, Levine BJ, Booth G, Lefer AM (2000) C-peptide inhibits leukocyte-endothelium interaction in the microcirculation during acute endothelial dysfunction. FASEB J $14: 2357-2364$

16. Baez S (1973) An open cremaster muscle preparation for the study of blood vessels by in vivo microscopy. Microvasc Res 5:384-394

17. Pierangeli SS, Colden-Stanfield M, Liu X, Barker JH, Anderson GL, Harris EN (1999) Antiphospholipid antibodies from antiphospholipid syndrome patients activate endothelial cells in vitro and in vivo. Circulation 99:1997-2002

18. Thorlacius H, Vollmar B, Seyfert UT, Vestweber D, Menger MD (2000) The polysaccharide fucoidan inhibits microvascular thrombus formation independently from $\mathrm{P}$ - and L-selectin function in vivo. Eur J Clin Invest 30:804-810

19. Vollmar B, Schmitz R, Kunz D, Menger MD (2001) Lack of in vivo function of $\mathrm{CD} 31$ in vascular thrombosis. Thromb Haemost 85:160-164

20. Lindenblatt N, Bordel R, Schareck W, Menger MD, Vollmar B (2004) Vascular heme oxygenase-1 induction suppresses microvascular thrombus formation in vivo. Arterioscler Thromb Vasc Biol 24:601-606

21. Baker M, Wayland H (1974) On-line volume flow rate and velocity profile measurements for blood in microvessels. Microvasc Res 7:131-143

22. Dunne JL, Ballantyne CM, Beaudet AL, Ley K (2002) Control of leukocyte rolling velocity in TNF-alpha-induced inflammation by LFA-1 and Mac-1. Blood 99:336-341

23. Kaul DK, Fabry ME, Costantini F, Rubin EM, Nagel RL (1995) In vivo demonstration of red cell-endothelial interaction, sickling and altered microvascular response to oxygen in the sickle transgenic mouse. J Clin Invest 96:2845-2853

24. Lindenblatt N, Schareck W, Belusa L, Nickels RM, Menger MD, Vollmar B (2003) Anti-oxidant ebselen delays microvascular thrombus formation in the rat cremaster muscle by inhibiting platelet P-selectin expression. Thromb Haemost 90:882-892

25. Kim MB, Sarelius IH (2004) Regulation of leucocyte recruitment by local wall shear rate and leucocyte delivery. Microcirculation 11:55-67

26. Ido Y, Vindigni A, Chang K et al (1997) Prevention of vascular and neural dysfunction in diabetic rats by C-peptide. Science 277:563-566

27. Rigler R, Pramanik A, Jonasson P et al (1999) Specific binding of proinsulin C-peptide to human cell membranes. Proc Natl Acad Sci USA 96:13318-13323

28. Horwitz DL, Starr JI, Mako ME, Blackard WG, Rubenstein AH (1975) Proinsulin, insulin, and C-peptide concentrations in human portal and peripheral blood. J Clin Invest 55:1278-1283

29. Shattil SJ, Cunningham M, Hoxie JA (1987) Detection of activated platelets in whole blood using activation-dependent monoclonal antibodies and flow cytometry. Blood 70:307-315
30. Kitabchi AE (1977) Proinsulin and C-peptide: a review. Metabolism 26:547-587

31. Schmitt A, Guichard J, Masse JM, Debili N, Cramer EM (2001) Of mice and men: comparison of the ultrastructure of megakaryocytes and platelets. Exp Hematol 29:1295-1302

32. Smyth SS, Tsakiris DA, Scudder LE, Coller BS (2000) Structure and function of murine alphaIIbbeta3 (GPIIb/IIIa): studies using monoclonal antibodies and beta3-null mice. Thromb Haemost 84:1103-1108

33. Wahren J (2004) C-peptide: new findings and therapeutic implications in diabetes. Clin Physiol Funct Imaging $24: 180-189$

34. Wojcikowski C, Fussgänger R, Pfeiffer E (1977) Inhibition of insulin and glucagon secretion of the isolated rat pancreas by synthetic human and rat C-peptide. In: Beyer J, Krause U, Naegele W (eds) C-peptide. Schnetzor, Konstanz, pp 75-88

35. Jensen ME, Messina EJ (1999) C-peptide induces a concentration-dependent dilatation of skeletal muscle arterioles only in presence of insulin. Am J Physiol Heart Circ Physiol 45: H1223-H1228

36. Ohtomo Y, Aperia A, Sahlgren B, Johansson BL, Wahren J (1996) C-peptide stimulates rat renal tubular $\mathrm{Na}^{+}, \mathrm{K}^{(+)}$-ATPase activity in synergism with neuropeptide Y. Diabetologia 39:199-205

37. Kunt T, Schneider S, Pfutzner A et al (1999) The effect of human proinsulin C-peptide on erythrocyte deformability in patients with type I diabetes mellitus. Diabetologia 42:465-471

38. Vague P, Coste TC, Jannot MF, Raccah D, Tsimaratos M (2004) C-peptide, $\mathrm{Na}^{+}, \mathrm{K}^{(+)}$-ATPase, and diabetes. Exp Diabesity Res 5:37-50

39. Forst T, Kunt T (2004) Effects of C-peptide on microvascular blood flow and blood hemorheology. Exp Diabesity Res 5:51-64

40. Alessi MC, Juhan-Vague I (2004) Contribution of PAI-1 in cardiovascular pathology. Arch Mal Coeur Vaiss 97:673-678

41. Juhan-Vague I, Morange PE, Alessi MC (2002) The insulin resistance syndrome: implications for thrombosis and cardiovascular disease. Pathophysiol Haemost Thromb 32:269-273

42. Schafer K, Muller K, Hecke A et al (2003) Enhanced thrombosis in atherosclerosis-prone mice is associated with increased arterial expression of plasminogen activator inhibitor1. Arterioscler Thromb Vasc Biol 23:2097-2103

43. Steinberg HO, Brechtel G, Johnson A, Fineberg N, Baron AD (1994) Insulin-mediated skeletal muscle vasodilation is nitric oxide dependent. A novel action of insulin to increase nitric oxide release. J Clin Invest 94:1172-1179

44. Chakraborty K, Sinha AK (2004) The role of insulin as an antithrombotic humoral factor. Bioessays 26:91-98

45. Nordt TK, Sawa H, Fujii S, Sobel BE (1995) Induction of plasminogen activator inhibitor type-1 (PAI-1) by proinsulin and insulin in vivo. Circulation 91:764-770

46. Trovati M, Anfossi G (2002) Influence of insulin and of insulin resistance on platelet and vascular smooth muscle cell function. J Diabetes Complications 16:35-40

47. Hu H, Li N, Ekberg K, Johansson BL, Hjemdahl P (2002) Insulin, but not proinsulin C-peptide, enhances platelet fibrinogen binding in vitro in type 1 diabetes mellitus patients and healthy subjects. Thromb Res 106:91-95

48. Hu H, Hjemdahl P, Li N (2002) Effects of insulin on platelet and leukocyte activity in whole blood. Thromb Res 107:209-215

49. Johansson BL, Borg K, Fernqvist-Forbes E, Kernell A, Odergren T, Wahren J (2000) Beneficial effects of C-peptide on incipient nephropathy and neuropathy in patients with type 1 diabetes mellitus. Diabet Med 17:181-189

50. Johansson BL, Borg K, Fernqvist-Forbes E, Odergren T, Remahl S, Wahren J (1996) C-peptide improves autonomic nerve function in IDDM patients. Diabetologia 39:687-695 